Chiscani, Braila. Thanks to increased paper production, more and more books dealing with national and world literature as well as technical and scientific works are being produced. For the new way of life in the Rumanian People's Republic requires men to be instructed.

For many years now the Delta is no longer " the cursed land". "Kherkhanadji ", malaria and poverty no longer exist. Today this region is known as the "land of man's happiness".

\title{
Viet Nam
}

\section{Democratic Repubic}

The Red Cross of the Democratic Republic of Viet Nam has recently had the brief Summary of the Geneva Conventions of August 12, 1949, translated and published in the Vietnamese language.

This is the same booklet which the International Committee of the Red Cross has distributed since 1952 in French, German, English, Arabic and Spanish for the use of members of the armed forces and of the public.

The Red Cross world will have satisfaction in knowing that these basic notions relative to the Geneva Conventions have thus been placed within the reach of the general public in the Democratic Republic of Viet Nam.

\section{Yugoslavia}

The Yugoslav Red Cross has been good enough to send the ICRC an illustrated booklet which it has had published ${ }^{1}$. Entitled "The health worker and the Geneva Conventions", and composed of 24 small-format pages, it is intended to popularize and make

\footnotetext{
1 Zdravstveni radnik i Zenevske Konvencije, Beograd, 1962.
} 
known the Conventions amongst medical and health personnel. With this end in view, it supplies all the explanations necessary for the correct application of these Conventions in general, as well as commentaries on the rights and duties of this personnel. It also contains a chapter referring to the International Red Cross, illustrated by photographs reproducing certain salient features marking its action during the course of various conflicts.

This booklet has been distributed to members of professional associations of doctors, nurses, pharmacists, as well as to members of the auxiliary personnel of the medical services and to persons who are intending to enter these professions through medical faculties and nursing schools.

The text is divided into fourteen chapters, the titles of which are as follows: What the Geneva Conventions are; The struggle for peace and the Geneva Conventions; The Red Cross and the Geneva Conventions ; The Federal People's Republic of Yugoslavia and the Geneva Conventions; History (Henry Dunant); The New Conventions; Who is entitled to Red Cross protection? Protected medical equipment; The duties of the samaritan; The rights of the samaritan; The Red Cross emblem; Composition of the International Red Cross ; Inadequacy of the Geneva Conventions ; The health worker and the Geneva Conventions.

This last chapter points out the difficult situation in which the health worker finds himself as a result of the heavy responsibilities which are incumbent upon him; consequently, he will be "the best agent for the dissemination of the Conventions, which he will defend and for the respect of which he will be ready to fight." We welcome the publication of this booklet which aims at instructing the health worker, so that he has an exact understanding of his practical action and of his humanitarian mission. 